\title{
Identification of Resistance Sources against Charcoal Rot of Sesame Incited by Macrophomina phaseolina (Tassi) Goid
}

\author{
Ramesh Nath Gupta ${ }^{1 *}$, H.S. Saharan ${ }^{1}$, A.S. Rathi ${ }^{1}$ and Ram Avtar ${ }^{2}$ \\ ${ }^{1}$ Department of Plant Pathology, ${ }^{2}$ Department of Genetics and Plant Breeding, \\ College of Agriculture, CCS HAU, Hisar-125004, India \\ *Corresponding author
}

\section{Keywords \\ Sesame, Germplasm, Charcoal rot, Macrophomina phaseolina, Resistance \\ Article Info \\ Accepted: 08 January 2020 Available Online: 10 February 2020}

\section{A B S T R A C T}

Charcoal rot caused by Macrophomina phaseolina (Tassi) Goid is one of the most devastating diseases of sesame and causes heavy losses worldwide. The disease is becoming severe in sesame growing areas due to increased level of inoculum in soil. The pathogen of charcoal rot disease becomes more destructive particularly when high temperature and water stress conditions occur during growing period of the crop. A field experiment was carried out for two consecutive years during Kharif 2017 and 2018 at oilseed research area, CCS HAU, Hisar for identification of resistance source against charcoal rot of sesame. Host resistance is an important component of integrated disease management for charcoal rot of sesame. Among various management practices against charcoal rot, breeding for the resistant varieties is effective, economic and eco-friendly method to overcome this problem. Resistant variety ensures protection against this disease, save the time, energy and money spent on other measures of control. Three hundred and fifty (350) sesame germplasm lines were evaluated for identification of the resistance source against charcoal rot disease. Among evaluated germplasm, majority of them showed moderately susceptible and susceptible reaction whereas two lines viz., NIC-8533 and S-1671 were identified as highly susceptible against charcoal rot disease. None of the germplasm line showed complete resistance while eighteen lines viz., NIC-7837, NIC-7875, NIC-17849, SI-2174-1, SI-3296, IS-922, HT-9913, IS-455-A, PCU-129, PCU-136, IC-303419, HT-20, HT-9907, KMR13, TC-159, TC-184, TC-318 and EC-303419 were identified as moderately resistant against charcoal rot of sesame. The information generated through this experiment can be utilized in horizontal resistance breeding programmes.

\section{Introduction}

Sesame (Sesamum indicum L.) is one of the most ancient and traditional oilseed crop. It is regarded as "Queen of oilseeds" due to its superior oil and stabilized keeping quality, contributed by high degree of resistance to oxidation (Bedigian and Harlan, 1986). Seeds 
have a good quality food, nutrition, biomedicine, health care and religious value. It is a rich source of vitamins $\left(\mathrm{E}, \mathrm{A}, \mathrm{B}_{1}, \mathrm{~B}_{2}\right.$, and $\mathrm{B}_{3}$ ) and minerals (calcium and phosphorus) and protein (methionine). Due to presence of potent antioxidant property and high nutritive value of sesame seed is regarded as "Seed of immortality." About 73 per cent of sesame oil is used for edible purpose, remaining oil used in manufacturing of paints, pharmaceuticals, food industries, insecticide industries for enhancing power of pyrethrin and lower grades of oil are used in soap industries (Hansen, 2011). It is an important oilseed crop widely grown in tropical and subtropical countries. In world, it is grown on 100 lakh hectares area with an average production of 55 lakh tonnes and $554 \mathrm{~kg} / \mathrm{ha}$ productivity (Anonymous, 2017). In India, area, production and productivity of sesame are 18 lakh hectares, 8 lakh tonnes and $448 \mathrm{~kg} / \mathrm{ha}$, respectively. In Haryana, it is grown during kharif season in area of 1600 hectares with 640 tonnes and $400 \mathrm{~kg} / \mathrm{ha}$ production and productivity, respectively (Anonymous, 2017).

Seeds are highly valued due to high nutritional and medicinal properties. Despite of its high nutritive, economic value and acreage, the production and productivity is low in the country due to several biotic and abiotic stresses. The crop is affected by several pathogens causing diseases and act as major damaging factor to sesame plants cultivated in the whole world with severe annual losses of 7 million tonnes (Ara et al., 2017). It is an important limiting factor for sesame production and affects severely at all crop growth stages. Murugesan et al., (1978) reported that $1.8 \mathrm{~kg} / \mathrm{ha}$ sesame yield losses was at every one per cent increase in charcoal rot intensity. Vyas (1981) also observed the seedling mortality due to seed borne infection which aggravated the disease, reduced the plant stand per unit area and resulted in 5$100 \%$ yield loss.
Host resistance is an important component for integrated disease management. The pathogen of charcoal rot is variable in nature and rapidly changes the resistant varieties into susceptible. Among various management practices, breeding for the resistant varieties is effective, economic and eco-friendly method to overcome the problem of charcoal rot of sesame. Resistant variety ensures protection against disease, save the time, energy and money spent on other measures of control. There are many reports in literature in which only indicated that out of tested germplasm lines, few lines were moderately resistant with having no mention of complete resistance (John et al., 2005; Rao, 2007; Farooq et al., 2019). Bedawy and Moharm (2019) also evaluated eighty six lines of sesame in which fourteen lines viz., 33, 3, 15, 64, 40, 63, 14, $39,4,16,13,80,58$ and 79 were identified as a moderately resistant against charcoal rot disease. Sesame germplasm lines collection and their exchange need to be strengthened, so that the large number of moderately resistant germplasm may be utilized in horizontal resistance breeding programmes.

\section{Materials and Methods}

The experiment was conducted in augmented design with single row in plot size of 3 metre row length for identification of resistance source against charcoal rot of sesame. Three hundred fifty germplasm lines were evaluated during kharif 2017 and 2018 under natural sick plot field conditions. The experimental plot became natural sick plot due to increased level of inoculum in soil by continuous growing of sesame in same field.

\section{Results and Discussion}

Three hundred fifty sesame germplasm lines were screened for their relative resistance against charcoal rot disease for consecutive two years. On the basis of per cent disease 
incidence, germplasm lines were classified under different categories (Table 1). Among them none of germplasm line showed resistant reaction (DI 1-10\%) against charcoal rot disease, however eighteen germplasm lines viz., EC-303419, HT-20, HT-9907, HT9913, IC-303419, IS-455-A, IS-92-2, KMR13, NIC-17849, NIC-7837, NIC-7875, PCU129, PCU-136, SI-2174-1, SI-3296, TC-159, TC-184 and TC-318 showed moderately resistant reaction (DI 11-20\%). Three hundred seven lines were found moderately susceptible (DI 21-30\%) whereas twenty three germplasm lines viz., ES-71-A, HT-2000, HTC-1, NH-28-27-3114, NIC-8508, TC-10, TC-14, TC-15, TC-163, TC- 16-A, TC-20, TC-22, TC-24, TC-25, TC-26, TC-27, TC304, TC-306, TC-315, TC-365, TC-42, TC-8 and TC-99 identified as susceptible (DI 3150\%). Germplasm lines NIC-8533 and SI1671 were identified as highly susceptible (DI $51-100 \%)$ against charcoal rot disease.

Table.1 Disease reactions of sesame germplasm lines screened under natural sick plot field conditions during kharif 2017 and 2018

\begin{tabular}{|c|l|l|}
\hline $\begin{array}{c}\text { Disease } \\
\text { Reaction }\end{array}$ & $\begin{array}{c}\text { Disease } \\
\text { incidence } \\
\mathbf{( \% )}\end{array}$ & \multicolumn{1}{|c|}{ Germplasm lines } \\
\hline $\begin{array}{c}\text { Resistant } \\
\text { Roderately }\end{array}$ & $1-10$ & Nil \\
\hline \multirow{2}{\text{Resistant}}{} & $11-20$ & EC-303419, HT-20, HT-9907, HT-9913, IC-303419, \\
IS-455-A, IS-92-2, KMR-13, NIC-17849, NIC-7837, \\
NIC-7875, PCU-129, PCU-136, SI-2174-1, SI-3296, \\
TC-159, TC-184, TC-318
\end{tabular}




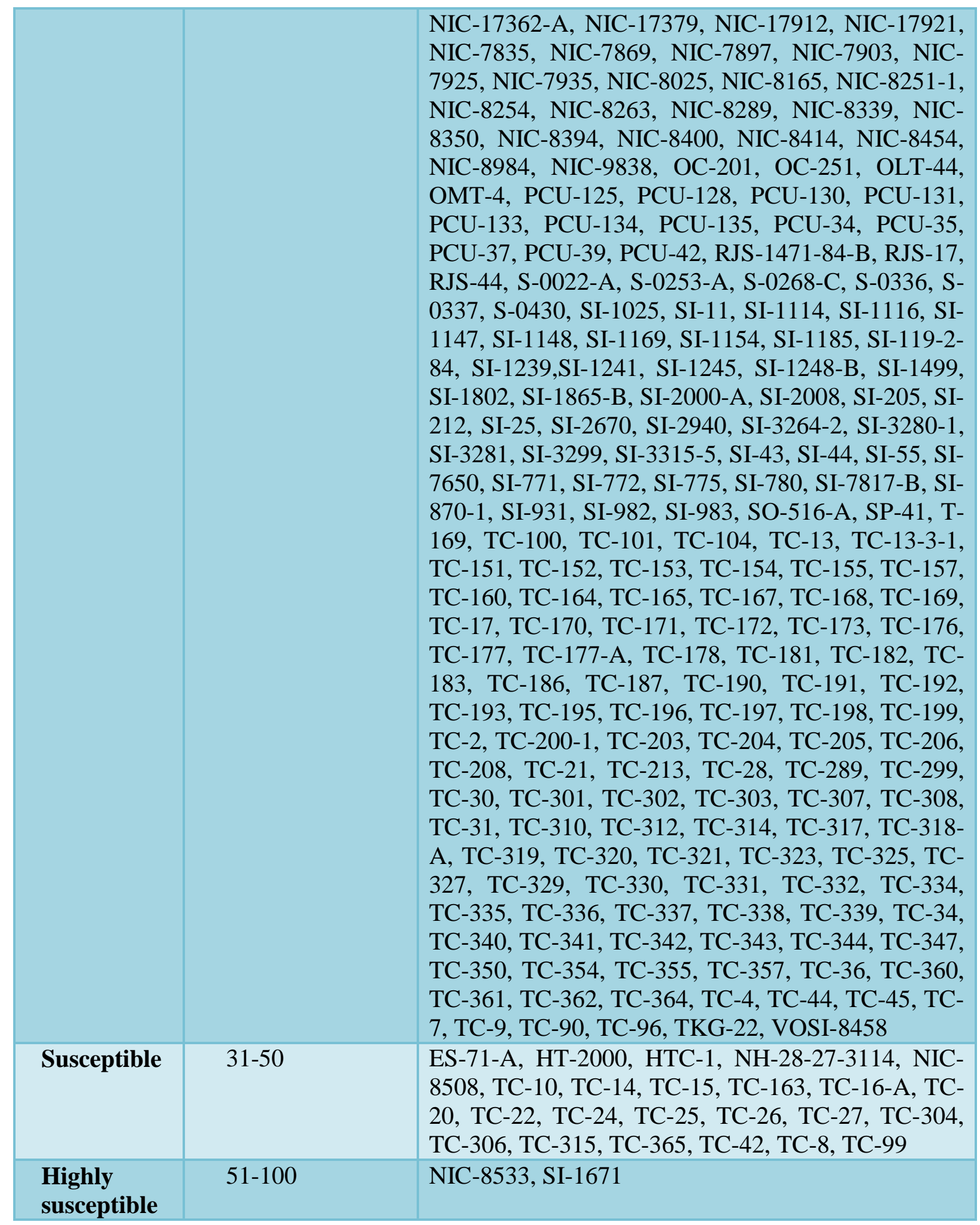

The ultimate and most economical and practical approach for managing charcoal rot disease would be the use of resistant variety.
Host resistance is an integral part of integrated disease management system therefore; it demands a continuous and 
comprehensive work on host pathogen responses. The complete resistance against charcoal rot is not reported from elsewhere with confirmation. Presently no known source of transferable resistance is available in cultivated varieties of sesame, efforts have been made to identify the resistant/moderately source against charcoal rot. The disease usually ignored due to lack of proper control and economics of fungicide applications at different stages of crop in farmers field. The pathogen continuously changes its nature and rapidly resistant varieties become susceptible (Chaudhary et al., 2001). However, the research on evaluating and identifying resistance sources against charcoal rot disease through hybridization techniques has been a continued process throughout country and everywhere. However, field resistance among available germplasm need to be assessed for further execution in resistance breeding programmes. Chowdhury et al., (2017) reported that infection stages of charcoal rot fungus $M$. phaseolina in sesame had a transition phase from biotrophy via BNS (biotrophy-to-necrotrophy switch) to necrotrophy as confirmed by their transcriptional studies. Microscopy using normal and GFP-expressing pathogen showed typical constricted thick intercellular bitrophic hyphae which gave rise to thin intracellular necrotrophic hyphae during BNS and this stage was delayed in a resistant host. Findings also showed that as the pathogen switched its strategy of infection, the host tailored its defence strategy to meet the changing situation. A total of twenty genes functioning in different aspects of plant defence that were monitored over a time course during the changing infection phases showed a coordinated response. Most importantly, this defence response was more prompt in the resistant than the susceptible host indicating that a resistant host makes different choices from a susceptible host during infection which ultimately influences the severity of the disease.

In present investigation, three hundred fifty germplasm lines were screened for their relative resistance against charcoal rot under natural sick plot field conditions. Due the continuously growing breeding material in same field for the last many years, we could get the ample opportunity to screen the material at parallel with the sick plot. Three hundred fifty germplasm lines were evaluated for their relative resistance under natural sick plot field conditions and majority of them showed moderately susceptible and susceptible reaction against charcoal rot. None of the germplasm showed resistant reaction, whereas only eighteen lines viz., EC303419, HT-20, HT-9907, HT-9913, IC303419, IS-455-A, IS-92-2, KMR-13, NIC17849, NIC-7837, NIC-7875, PCU-129, PCU-136, SI-2174-1, SI-3296, TC-159, TC184 and TC-318 were identified as moderately resistant against charcoal rot disease.

Complete resistance is not available against this wide host range disease also reported by various workers (Avila, 2003; Anwar et al., 2006; Rao, 2007; Deepthi et al., 2014; Shabana et al., 2014; Farooq et al., 2019; Bedawy and Moharm (2019). However, many lines have been identified as moderately resistant against the charcoal rot disease. The necrotrophic pathogens may have many minor genes for specificity or either no gene for host specificity; however they have genes for pathogenicity to infect many plant species. Since, completely resistant genotype in sesame against charcoal rot is not available with breeders; hence, it is difficult to breed resistant variety with good yield. Therefore, the germplasm lines showing moderate resistance need to be assessed for their yield and other yield contributing characters, so that they can be further applied in horizontal resistance breeding programmes. 


\section{References}

Anonymous (2017). Production of Crops. FAOSTAT, Food and Agriculture Organization of the United Nation.

Anonymous (2017). Selected state-wise Area, Production and Productivity of Sesamum in India (2016-2017). Ministry of Agriculture and Farmers Welfare, Government of India.

Anwar, M., Ejaz-ul-Hasan, Bibi, T., Mustafa, H.S.B., Mahmood, T. and Ali, M. (2006). TH-6: a high yielding cultivar of sesame released for general cultivation in Punjab. Advancement in Life Sciences, 1(1): 4451.

Ara, A., Akram, A., Ajmal, M., Akhund, S., Nayyar, B.G., Seerat, W. and Chaudhry, S.M (2017). Histopathological studies of sesame (Sesamum indicum) seedlings infected with Fusarium oxysporum. Plant Pathology and Quarantine. 7(1): 82-90.

Avila, M.J. (2003). Resistance of white seeded sesame (Sesamum indicum L.) cultivars against charcoal rot (Macrophomina phaseolina) in Venezuela. Sesame and Safflower Newsletter, 18: 72-76.

Bedawy, I.M.A. and Moharm, M.H.A. (2019). Reaction and performance of some sesame genotypes for resistance. Alexandria Science Exchange Journal, 40: 12-18.

Bedigian, D. and Harlan, J.R. (1986). Evidence for cultivation of sesame in the ancient world. Economic Botany, 40: 137-154.

Chaudhary, M.H.Z., Sarwar, N. and Chaughati, F.A. (2001). Biochemical changes in chickpea plant after induction treatment with simple chemical for systemic resistance against Ascochyta blight in the field. Journal of Chemical Society of Pakistan, 23: 182-186.

Chowdhury, S., Basu, A. and Kundu, S. (2017). Biotrophy-necrotrophy switch in pathogen evoke differential response in resistant and susceptible sesame involving multiple signaling pathways at different phases. Nature Scientific Reports, 7(1): 1-17.

Deepthi, P., Shukla, C.S., Verma, K.P. and Reddy, E.S.S. (2014). Identification of charcoal rot resistant lines of Sesamum indicum and chemical management of Macrophomina phaseolina. Medicinal Plants, 6(1): 36-42.

Farooq, S., Mohyo-Ud-Din, A., Maz, S., Siddique, M. and Khan, S.N. (2019). Screening of sesame (Sesamum indicum L.) germplasm for resistance against charcoal rot disease caused by Macrophomina phaseolina (Tassi) Goid. International Journal of Biology and Biotechnology, 16(2): 402-407.

Hansen, R. (2011). Sesame profile. Agricultural Marketing Resource Center.

John, P., Tripathi, N.N. and Kumar, N. (2005). Evaluation of sesame germplasm or cultivars for resistance against charcoal rot. Research on Crops, 6(1): $152-153$.

Murugesan, M., Shanmugam, N., Menon, P.P.V., Arokiaraj, A., Dhamo, K.P. and Kochubabu, M. (1978). Statistical arrangement of yield loss of sesame due to insect pests and diseases. Madras Agriculture Journal, 65: 290-295.

Rao, S.V.S.G. (2007). A promising sesame (Sesamum indicum L.) culture YLM-66. Madras Agricultural Journal, 94(1): 103104.

Shabana, R., El-Mohsen, A.A.A., Khalifa, M.M.A. and Saber, A.A. (2014). Quantification of resistance of $F 6$ sesame elite lines against Charcoal rot and Fusarium wilt diseases. Advance in Agriculture and Biology, 2(3): 144-150.

Vyas, S.C. (1981). Diseases in sesame in India and their control. Pesticides, 15: 910. 


\section{How to cite this article:}

Ramesh Nath Gupta, H. S. Saharan, A.S. Rathi and Ram Avtar. 2020. Identification of Resistance Sources against Charcoal Rot of Sesame Incited by Macrophomina phaseolina (Tassi) Goid. Int.J.Curr.Microbiol.App.Sci. 9(02): 1795-1801.

doi: https://doi.org/10.20546/ijcmas.2020.902.205 